\section{Academic freedom}

\section{Promise for Poles}

Poland is to introduce new legislation designed to meet the demands of the academic milieu for greater autonomy, according to Janusz Gorski, the Minister of Science, Higher Education and Technology. The first draft of the new bill should go before paliament in December, but many of its provisions regulating dealings between his ministry and the universities would come into force immediately. In particular, he said, the ministry would not appoint university rectors without prior consultation with the university senates.

Another development in the Polish academic world concerns the University of Warsaw, which has in the past couple of weeks had a sudden change of rector. The highly unpopular Dr Zygmunt Rybicki resigned shortly before the opening of the academic year, to be hastily replaced by historian Dr Henryk Samsonowicz. The significance of this change is not entirely clear - Polish academic life, like Polish life in general, is something of a melting pot at present. However, on 28 September, the university senate issued a statement which is, in effect, a blueprint for the restoration of academic autonomy.

The statement pays tribute to the new "self-governing" trade union movement, which has now spread to the university students, and makes a number of demands for the liberalization of society as a whole, including electoral and censorship reform. It then discusses the role of the universities which it says is, basically, to "carry out scientific research and to serve national culture and public education". Science, and the results of research, said the senate, should be implemented for the benefit of society a commission of experts should be established, and science should be involved in decision-making at all levels.

The statement advocates open and unhampered discussion and demands a basic reform of the higher education system. The main points of such a reform, said the Warsaw senate, should be:

(1) Self-governing and democratic status of universities and colleges of higher education, collegiate bodies, senates and faculties to decide on directions of research; secret elections of these bodies, with students and the working staff of the institution also represented; curricula to be decided in consultation with the relevant ministries.

(2) Free access to publications and sources of scientific information.

(3) Proper means and conditions of work guaranteed to students and staff.

(4) Freedom for students to organize their own lives.

(5) Academic appointments to be made on the basis of qualifications only.

(6) The Supreme Scientific Council to possess all necessary competence for shaping academic policy.

(7) The awarding of academic degrees to be the business of the collegiate bodies, faculties and senates, the Central Commission for Qualifications and the Council of State.

The question is, of course, how far these proposals will be implemented in the new legislation. Minister Gorski suggest that there will be some reforms in the awarding of higher degrees by the Central Commission for Qualifications.

However, the proposals announced for improvements in the student grant system have clearly met with less enthusiasm than Gorski had expected. The majority of Polish students, who have flocked to join the new "self-governing" student unions, appear more concerned with the lifting of censorship restrictions.

One good omen for the future, however: Miroslaw Chojecki, the young chemist dismissed in 1977 from the Swierk Nuclear Institute because of his membership of the then Workers' Defence Committee and on trial earlier this year for participation in the "independent" publishing movement, has been reinstated under the terms of the Gdansk accords. At least half of the Swierk staff, said Chojecki, personally endorsed his application for reinstatement.

Vera Rich

\section{Endangered species}

\section{Mediterranean acts}

The fifteen or so well-managed nature reserves around the Mediterranean are around ten times too few, the International Union for the Conservation of Nature (IUCN) is arguing at an intergovernmental meeting in Athens this week. Papers produced by IUCN for the meeting specify dozens of threatened species of mammals, amphibians, fish and plants.

The principal threat is tourism expected to reach 200 million tourists a year by the year 2000 - with its demands for coastal hotels, marinas, and baubles such as coral, sponges and tortoiseshell.

The most endangered species is the monk seal, Monachus monachus. Besides one colony on the coast of Mauritania in West Africa, there are just 1,000 monk seals around Turkey, Greece, Yugoslavia and Tunisia, and numbers are falling by a hundred or so each year. Numbers are now so low, and groups so dispersed, that the seals are threatened by restricted genetic diversity. The marine turtle is in similar danger, as the beaches where it lays its eggs are turned over to tourism. Other species at risk include the Iberian midwife toad, the Mediterranean spur-thighed tortoise, the

\title{
Biggest radio telescope in the world
}

The Very Large Array radiointerferometer was inaugurated last week in New Mexico by Dr Frank Press, the President's Science Advisor.

The array, which consists of twenty-seven steerable parabolic dishes 82 feet in diameter, has been brought progressively into operation since October 1975.
Individual dishes move along three double railway tracks at angles of 120 degrees two of the tracks are 13 miles long and the third is more than 11 miles long. The array, operated as a national research facility by the National Science Foundation, is capable of greater angular resolution than any other instrument of its kind.

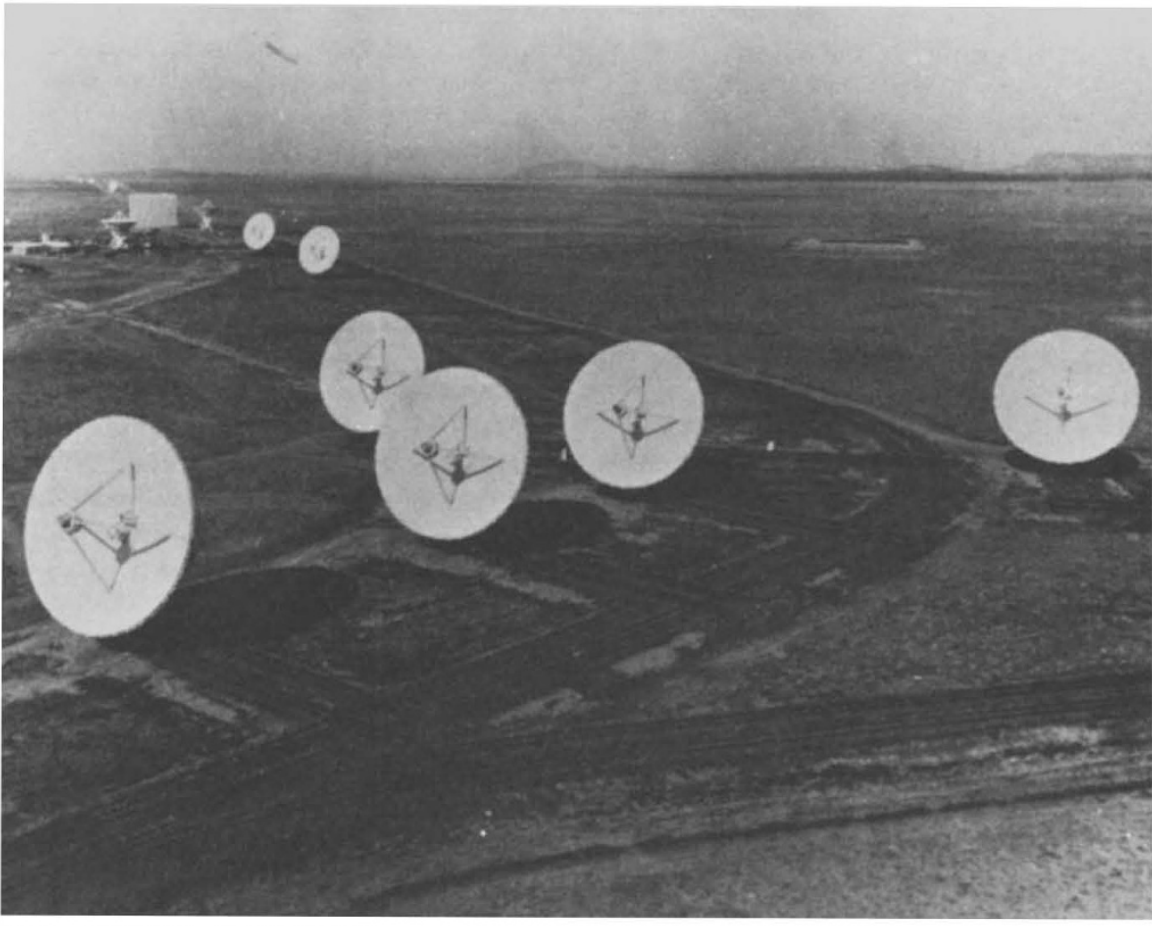

